\title{
Uji Efektivitas Ekstrak Biji Lamtoro (Leucaena leucocephala) sebagai Insektisida terhadap Kecoa Amerika (Periplaneta americana)
}

\author{
Yuanda Adelia ${ }^{1 *}$, Damayanti Iskandar ${ }^{1}$ \\ ${ }^{1}$ Program Studi Kimia, Fakultas Sains dan Teknologi, Universitas Islam Negeri Raden Fatah \\ Palembang, Sumatra Selatan, Indonesia
}

\author{
Corresponding author: \\ Yuanda Adelia \\ yuanda.adelia30@gmail.com \\ Received: June 2020 \\ Accepted: August 2020 \\ Published: September 2020 \\ (C)Yuanda Adelia et al. This is \\ an open-access article \\ distributed under the terms \\ of the Creative Commons \\ Attribution License, which \\ permits unrestricted use, \\ distribution, and \\ reproduction in any \\ medium, provided the \\ original author and source \\ are credited.
}

\begin{abstract}
Research on the effectiveness of lamtoro seeds (Leucaena leucocephala) extract has been carried out as an insecticide against American cockroaches (Periplaneta americana). The lamtoro seeds were extracted using maceration method with ethanol solvent, and obtained ethanol extract of lamtoro seeds. Lamtoro seeds extract was made in 5 concentrations of $0 \%$, $2 \%, 6 \%, 10 \%$ and $14 \%$. The effectiveness of the extract was tested using spray method with 10 adult cockroaches as a testing animal with 3 times repetition and observed for 72 hours. Observations have shown the decline in American cockroaches' activity is causing death. Mortality data were analyzed using probit analysis to determine LC50. The result of phytochemical test of lamtoro seeds extract are flavonoids, tannins and saponins. Lamtoro seeds extract was effective to kill American cockroaches, which percentage of mortality were $0 \%, 33 \%, 66 \%, 86 \%$ and $96 \%$ respectively at concentration $0 \%, 2 \%, 6 \%, 10 \%$, and $14 \%$ with LC $303,35 \%$.
\end{abstract}

Keywords: effectiveness of insecticides, lamtoro seed extract, Periplaneta americana, flavonoids, saponins, tannins, $L C_{50}$

\section{Pendahuluan}

Lingkungan merupakan faktor penting yang mempengaruhi aktivitas manusia. Keadaan lingkungan yang kurang bersih menjadi salah satu penyebab berkembangnya vektor penyakit dan salah satunya adalah serangga. Menurut Permenkes No. 50 Tahun 2017, sekitar 426,480 orang terjangkit penyakit akibat vektor serangga ${ }^{[1]}$. Kecoa adalah salah satu serangga yang dapat menimbulkan bahkan menularkan berbagai macam penyakit baik secara langsung maupun tidak langsung. Penyakit seperti alergi, gangguan pencernaan, diare, disentri, tifus, kolera dan polio merupakan beberapa penyakit yang dapat ditularkan oleh kecoa ${ }^{[2]-[4]}$. Keberadaan kecoa sangat dekat hubungannya dengan manusia, kecoa hidup dirumah, hotel, dapur dan lain-lain. Salah satu jenis kecoa yang sering ditemukan dilingkungan pemukiman adalah kecoa amerika (Periplaneta americana).

Pengendalian kecoa dapat dilakukan dengan berbagai cara dan salah satunya melalui penggunaan insektisida. Masyarakat didunia, khususnya di Indonesia lebih menyukai penggunaan insektisida sintetis sebagai pembasmi serangga. Penggunaan insektisida sintetis secara berkepanjangan memiliki efek yang kurang aman bagi lingkungan karena sifatnya yang sulitterurai. Menurut Badan Kesehatan Dunia (WHO) sekitar 20,000 orang meninggal akibat pencemaranl ingkungan dari penggunaan pestisida sintetis serta 5,000-10,000 orang mengalami dampak yang sangat fatal[5]. Residu insektisida sintetis juga berdampak 
pada kesehatan manusia diantaranya meningkatkan resiko kemandulan, keguguran dan paparannya terhadap anak-anak dapat menurunkan stamina dan kecerdasan anak ${ }^{[6]}$. Sehingga, perlu dilakukan penelitian mengenai alternatif pengendalian serangga seperti insektisida alami.

Insektisida alami merupakan jenis insektisida yang berasal dari tumbuhan. Insektisida alami diyakini memiliki efek buruk yang lebih sedikit bagi kesehatan manusia dan lingkungan jika dibandingkan dengan insektisida sintetis. Senyawa metabolit sekunder yang terkandung di dalam suatu tumbuhan memiliki potensi sebagai insektisida. Pada penelitian ini, dimanfaatkan senyawa metabolit sekunder yang berasal dari biji lamtoro sebagai insektisida alami dalam pengendalian serangga. Chahyono dan Suryana mengemukakan bahwa biji lamtoro mengandung semyawa aktif seperti flavonoid, tanin, saponin, alkaloid dan mimosin [7],[8]. Namun, sampai saat ini belum ada informasi mengenai pemanfaatan biji lamtoro sebagai insektisida alami. Dalam memperoleh senyawa metabolit sekunder suatu tanaman alternatif yang dapat dilakukan untuk yaitu dengan metode ekstraksi, dimana bagian tanaman yang digunakan diekstrak dengan menggunakan pelarut organik. Berdasarkan hal tersebut, maka pada penelitian ini dilakukan pengujian efektivitas ekstrak biji lamtoro sebagai insektisida alami terhadap kecoa amerika. Pengamatan dilakukan selama 3 hari dan dari penelitian ini juga akan diperoleh nilai $\mathrm{LC}_{50}$ untuk mengetahui pada konsentrasi berapa ekstrak biji lamtoro dapat mematikan 50\% dari populasi kecoa amerika yang digunakan sebagai bioindikator ujinya.

\section{Metodologi Penelitian}

\section{Bahan kimia}

Bahan yang digunakan dalam penelitian ini, yaitu serbuk biji lamtoro, etanol $96 \%$, reagen Mayer, reagen Wagner, serbuk $\mathrm{Mg}, \mathrm{HCl}, \mathrm{H}_{2} \mathrm{SO}_{4}$, $\mathrm{FeCl}_{3} 10 \%, \mathrm{CHCl}_{3}$, akuades dan kecoa amerika.

\section{Peralatan}

Alat yang digunakan pada penelitian ini, yaitu gelas ukur, neraca analitik (Ohaus Pionner), gelas beaker, cawan petri, batang pengaduk, spatula, blender, seperangkat alat rotary evaporator (Buchi), kertas saring, aluminium foil dan alat tulis.

\section{Prosedur penelitian}

\section{Preparasi sampel}

Biji tanaman lamtoro diperoleh dari Kelurahan 8 Ilir, Kecamatan Ilir Timur III Palembang, Sumatra Selatan. Biji lamtoro dikeringkan selama \pm 7 hari, setelah kering biji lamtoro dihaluskan menggunakan blender sehingga diperoleh serbuk biji lamtoro dan disaring.

\section{Ekstraksi biji lamtoro}

Serbuk biji lamtoro yang diperoleh dimaserasi dalam etanol 96\% selama $3 \times 24$ jam, kemudian disaring. Ekstrak dipekatkan dengan rotary evaporator pada suhu $40{ }^{\circ} \mathrm{C}$ [3], sehingga diperoleh ekstrak pekat. Ekstrak pekat yang diperoleh dilakukan pengujian skrining fitokimia dan dilakukan variasi konsentrasi untuk diaplikasikan pada pengujian daya ekstrak biji lamtoro sebagai insektisida alami.

\section{Skrining fitokimia}

\section{Uji flavonoid}

Ekstrak biji lamtoro sebanyak $2 \mathrm{ml}$ dimasukkan ke dalam tabung reaksi lalu ditambahkan $1 \mathrm{~g}$ serbuk $\mathrm{Mg}$ dan larutan $\mathrm{HCl}$. Perubahan warna menjadi jingga, kuning atau merah menunjukkan adanya kandungan flavonoid ${ }^{[9]}$.

\section{Uji tanin}

Ekstrak biji lamtoro sebanyak $2 \mathrm{ml}$ dimasukkan ke dalam tabung reaksi lalu ditambahkan 1-3 teteslarutan $\mathrm{FeCl}_{3}$. Perubahan warna menjadi biru kehitaman atau hijau kehitaman menunjukkan adanya senyawa tanin[9]. 


\section{Uji alkaloid}

Ekstrak biji lamtoro sebanyak $2 \mathrm{ml}$ dimasukkan ke dalam tabung reaksi lalu ditambahkan larutan $\mathrm{HCl}$ kemudian dipisahkan ke dalam 2 tabung reaksi. Masing-masing tabung ditambahkan beberapa tetes reagen Meyer dan reagen Wagner. Terbentuknya endapan putih hingga kuning pada tabung pertama menunjukkan adanya senyawa alkaloid dan terbentuknya warna coklat kemerahan pada tabung kedua menunjukkan adaya senyawa alkaloid ${ }^{[9]}$.

\section{Uji steroid}

Ekstrak biji lamtoro sebanyak $2 \mathrm{ml}$ dimasukkan ke dalam tabung reaksi lalu ditambahkan $2 \mathrm{~mL}$ $\mathrm{CHCl}_{3}$ kemudian ditambahkan 5 tetes $\mathrm{H}_{2} \mathrm{SO}_{4}$. Perubahan warna menjadi coklat menunjukkan adanya senyawa steroid[10].

\section{Uji saponin}

Ekstrak biji lamtoro sebanyak $2 \mathrm{ml}$ dimasukkan ke dalam tabung reaksi lalu ditambahkan $5 \mathrm{~mL}$ air hangat kemudian dikocok dan ditambahkan larutan $\mathrm{HCl}$. Terbentuknya buih stabil menunjukkan adanya kandungan saponin ${ }^{[10]}$.

\section{Persiapan hewan uji}

Serangga uji atau kecoa amerika diambil secara acak. Sebanyak 10 ekor kecoa amerika dewasa dimasukkan dalam rak uji atau kandang untuk dilakukan percobaan.

\section{Pembuatan larutan uji}

Pada penelitian ini, peneliti menggunakan 5 variasi konsentrasi larutan uji yaitu $0 \%$ (kontrol), 2\%, 6\%, 10\%, 14\%. Pengujian dilakukan sebanyak 3 kali ulangan pada setiap konsentrasi. Pengamatan dilakukan selama 72 jam setelah penyemprotan larutan uji dengan pembagian waktu pada jam ke-3, jam ke-6, jam ke-9, jam ke-12, jam ke-24, jam ke-48 dan jam ke-72.

\section{Metode analisa data}

Perubahan yang diamati meliputi kematian, perubahan aktivitas serta morfologi kecoa amerika. Data yang diperoleh dianalisis menggunalan metode analisa probit untuk memperoleh nilai LC 50 . LC 50 merupakan suatu perhitungan yang digunakan dalam menentukan keaktifan dari suatu ekstrak atau pada konsentrasi berapa ekstrak dapat mematikan $50 \%$ dari organisme uji ${ }^{[11]}$. Menurut Susilowati, cara perhitungan $\mathrm{LC}_{50}$ adalah ${ }^{[12]}$ :

a. Menghitung \% mortalitas dengan cara:

$$
\% \text { mortalitas }=\frac{\text { Jumlah serangga mati }}{\text { Jumlah total serangga }} \times 100 \%
$$

b. Jika terdapat serangga uji yang mati maka hitung mortalitas terkoreksi ulangan.

$\% \mathrm{MT}=\frac{\% \text { mortalitas perlakuan- } \% \text { mortalitas kontrol }}{100 \text {-jumlah serangga mati pada kontrol }}$

c. Mencari nilai probit untuk mortalitas terkoreksi yang didapatkan dengan memasukkan ke kolom nilai probit. Jika nilai probit sudah ada, membuat grafik hubungan antara nilai probit dengan $\log _{10}$ konsentrasi.

d. Mencari nilai $\mathrm{LC}_{50}$ dengan mencari nilai $\mathrm{x}$ dengan memasukkan nilai ke persamaan yang didapatkan. Kemudian tentukan nilai LC50 dengan antilog (x) atau 10x.

\section{Hasil dan Diskusi}

\section{Skrining fitokimia}

Ekstrak biji lamtoro yang telah diperoleh dilakukan skrining fitokimia untuk mengetahui senyawa metabolit sekunder yang terkandung di dalam ekstak biji lamtoro. Hasil uji fitokimia ekstak biji lamtoro dapat dilihat pada Tabel 1 .

Berdasarkan hasil skrining fitokimia ekstrak biji lamtoro yang ditunjukkan pada Tabel 1, dapat diketahui bahwa ekstrak biji lamtoro mengandung senyawa aktif yang dapat berperan sebagai insektisida alami diantaranya adalah flavonoid, saponin, dan tanin. 
Tabel 1. Hasil uji skrining fitokimia ekstrak biji lamtoro

\begin{tabular}{cllll}
\hline Senyawa & \multicolumn{1}{c}{ Metode } & Hasil positif & \multicolumn{1}{c}{ Hasil } & Ket \\
\hline & & & \\
Flavonoid & Ekstrak + serbuk & Perubahan warna & Perubahan warna & + \\
& $\mathrm{Mg}+\mathrm{HCl}$ pekat & menjadi kuning, & menjadi warna & jingga atau merah \\
& & & \\
\end{tabular}

\begin{tabular}{|c|c|c|c|c|}
\hline Tanin & $\begin{array}{l}\text { Ekstrak + larutan } \\
\mathrm{FeCl}_{3}\end{array}$ & $\begin{array}{l}\text { Perubahan warna } \\
\text { menjadi warna biru } \\
\text { kehitaman atau } \\
\text { hijau kehitaman }\end{array}$ & $\begin{array}{l}\text { Perubahan warna } \\
\text { menjadi hijau } \\
\text { kehitaman }\end{array}$ & + \\
\hline
\end{tabular}

$\begin{array}{lll}\text { Ekstrak }+\mathrm{HCl}+ & \text { Terbentuk endapan } & \text { Perubahan warna } \\ \text { reagen Mayer } & \text { putih hingga jingga } & \text { menjadi merah bata }\end{array}$

Alkaloid

$\begin{array}{lll}\text { Ekstrak }+\mathrm{HCl}+ & \begin{array}{l}\text { Perubahan warna } \\ \text { menjadi coklat }\end{array} & \begin{array}{l}\text { Perubahan warna } \\ \text { kemen wagner }\end{array}\end{array}$

$\begin{array}{lll}\text { Skstrak }+ & \begin{array}{l}\text { Terbentuk warna } \\ \text { kloroform }+\mathrm{H}_{2} \mathrm{SO}_{4} \\ \text { pekat }\end{array} & \begin{array}{l}\text { Perubahan warna } \\ \text { coklat }\end{array}\end{array}$

$\begin{array}{lll}\text { Saponin } & \begin{array}{l}\text { Terbentuknya buih } \\ (\text { dikocok })+\mathrm{HCl}\end{array} & \begin{array}{l}\text { stabil selama } 10 \\ \text { menit }\end{array}\end{array} \quad$ Buih stabil $\quad+$

Keterangan $\quad:(+)=$ Mengandung senyawa metabolit sekunder

$(-)$ = Tidak mengandung senyawa metabolit sekunder

\section{Hasil pengujian mortalitas kecoa amerika}

Pengujian mortalitas kecoa dilakukan selama 72 jam, hasil pengujian dapat dilihat pada Tabel 2. Hasil pengamatan yang dilakukan menunjukkan bahwa ekstrak biji lamtoro berpengaruh terhadap mortalitas kecoa amerika. Berdasarka Tabel 2 diketahui bahwa pada konsentrasi $0 \%$ (kontrol) rata-rata persentase mortalitas kecoa amerika sebesar $0 \%$. Sedangkan pada konsentrasi $2 \%$ sebesar $33 \%$, konsentrasi $6 \%$ sebesar $66 \%$, konsentrasi $10 \%$ sebesar $86 \%$ dan konsentrasi $14 \%$ sebesar $96 \%$. Dari data tersebut menunjukkan peningkatan mortalitas kecoa amerika. Hal ini disebabkan karena perbedaan konsentrasi ekstrak biji lamtoro yang digunakan, semakin tinggi konsentrasi ekstrak yang digunakan menunjukkan semakin tinggi kandungan senyawa aktif di dalamnya. Hal ini sesuai dengan penelitian Wahyuni yang menyatakan bahwa peningkatan konsetrasi berbanding lurus dengan peningkatan bahan racun tersebut, sehingga meningkatkan daya bunuh[3].

Pengamatan yang dilakukan menunjukkan bahwa konsentrasi 2-14\% ekstrak biji lamtoro mampu membunuh 3-10 ekor per 10 ekor 
hewan uji. Pada Tabel 2 rata-rata persen mortalitas kecoa amerika berada pada kisaran 33\%-96\%. Berdasarkan persen mortalitas tersebut dapat diketahui bahwa ekstrak biji lamtoro tergolong dalam tingkat efektivitas tipe cukup lemah hingga sangat kuat.

Mortalitas kecoa amerika disebabkan karena kandungan metabolit sekunder yang terdapat di dalam ekstrak biji lamtoro masuk ke dalam tubuh kecoa amerika dan mengakibatkan gangguan metabolisme. Gangguan metabolisme yang terjadi berupa gangguan pernapasan dan sistem saraf pada kecoa amerika. Hal ini sejalan dengan pendapat Umami yang menyatakan bahwa kandungan senyawa aktif pada suatu ekstrak dapat menyebabkan gangguan metabolism pada serangga[11]. Berdasarkan hal tersebut, maka ekstrak biji lamtoro bertindak sebagai racun kontak dan racun pernapasan. Perbedaan morfologi kecoa amerika yang terpapar ekstrak biji lamtoro dan yang tidak terpapar dapat dilihat pada Gambar 1.

Saponin masuk ke dalam tubuh serangga dengan cara menembus integument serangga, trakea atau kelenjar sensorik dan organ lain yang berhubungan dengan kutikula. Senyawa aktif yang terkandung dalam ekstrak biji lamtoro ini dapat melarutkan lemak atau lapisan lilin pada kutikula, sehingga menyebabkan senyawa aktif insektisida alami tersebut menembus tubuh seranga[13].

Tabel 2. Hasil pengujian mortalitas kecoa amerika

\begin{tabular}{|c|c|c|c|c|c|c|c|c|c|c|}
\hline \multirow{2}{*}{$\begin{array}{c}\text { Konsentrasi } \\
(\%)\end{array}$} & \multirow{2}{*}{$\begin{array}{l}\text { Jumlah } \\
\text { Kecoa }\end{array}$} & \multicolumn{7}{|c|}{ Mortalitas Kecoa (Jam ke-) } & \multirow{2}{*}{ \%Kematian } & \multirow{2}{*}{$\begin{array}{c}\text { Rata-rata } \\
\text { \%Kematian }\end{array}$} \\
\hline & & 3 & 6 & 9 & 12 & 24 & 48 & 72 & & \\
\hline \multirow{3}{*}{0} & \multirow{3}{*}{10} & 0 & 0 & 0 & 0 & 0 & 0 & 0 & $0 \%$ & \multirow{3}{*}{$0 \%$} \\
\hline & & 0 & 0 & 0 & 0 & 0 & 0 & 0 & $0 \%$ & \\
\hline & & 0 & 0 & 0 & 0 & 0 & 0 & 0 & $0 \%$ & \\
\hline \multirow{3}{*}{2} & \multirow{3}{*}{10} & 0 & 0 & 0 & 1 & 3 & 3 & 3 & $30 \%$ & \multirow{3}{*}{$33 \%$} \\
\hline & & 0 & 0 & 0 & 1 & 2 & 3 & 3 & $30 \%$ & \\
\hline & & 0 & 0 & 1 & 2 & 3 & 3 & 4 & $40 \%$ & \\
\hline \multirow{3}{*}{6} & \multirow{3}{*}{10} & 0 & 2 & 4 & 4 & 6 & 7 & 7 & $70 \%$ & \multirow{3}{*}{$66 \%$} \\
\hline & & 0 & 0 & 1 & 3 & 5 & 7 & 7 & $70 \%$ & \\
\hline & & 0 & 1 & 3 & 3 & 4 & 6 & 6 & $60 \%$ & \\
\hline \multirow{3}{*}{10} & \multirow{3}{*}{10} & 2 & 4 & 5 & 7 & 8 & 9 & 9 & $90 \%$ & \multirow{3}{*}{$86 \%$} \\
\hline & & 2 & 3 & 3 & 5 & 6 & 8 & 8 & $80 \%$ & \\
\hline & & 1 & 3 & 4 & 4 & 7 & 9 & 9 & $90 \%$ & \\
\hline \multirow{3}{*}{14} & & 4 & 6 & 8 & 9 & 10 & 10 & 10 & $100 \%$ & \multirow{3}{*}{$96 \%$} \\
\hline & 10 & 4 & 5 & 6 & 6 & 7 & 9 & 9 & $90 \%$ & \\
\hline & & 3 & 5 & 7 & 7 & 9 & 10 & 10 & $100 \%$ & \\
\hline
\end{tabular}




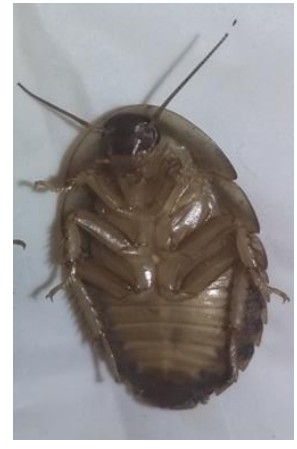

(a)

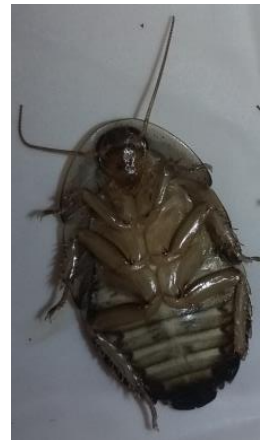

(b)

Gambar 1. (a) Kecoa amerika tidak terpapar ekstrak biji lamtoro (b) Kecoa amerika terpapar ekstrak biji lamtoro.

Senyawa saponin yang masuk ke dalam tubuh serangga akan mengakibatkan penurunan asupan nutrisi bagi serangga. Hal ini disebabkan, karena senyawa saponin dapat bertindak sebagai inhibitor enzim protease yang menyebabkan penurunan asupan nutrisi serangga dan membentuk kompleks dengan

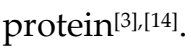

Senyawa tanin yang masuk ke dalam tubuh kecoa dapat mengakibtakan penurunan aktivitas sel. Mekanisme kerja senyawa tanin adalah dengan cara mengkerutkan dinding sel atau membrane sel pada kecoa, sehingga permeabilitas sel menjadi terganggu dan mengakibatkan sel tidak dapat melakukan aktivitasnya dan terhambatnya pertumbuhan serangga. Senyawa tanin juga dapat menginduksi pembentukan kompleks tanin terhadap ion logam dan meningkatkan toksisitas $\operatorname{tanin}[3],[14]$.

Sebagai racun pernapasan, kecoa amerika menghirup ekstrak biji lamtoro melalui trakea. Senyawa flavonoid masuk ke dalam tubuh kecoa amerika bersama oksigen melalui spirakel. Oksigen dan uap senyawa yang masuk akan diteruskan ke trakeolus menuju sistem pernapasan melalui jaringan yang menyebabkan penurunan fungsi oksigen dan terjadinya kerusakan pada spirakel serta gangguan saraf yang berakhir kematian. Hal ini sejalan dengan pendapat Gifari yang menyatakan bahwa senyawa yang terdapat pada insektisida dapat masuk melalui sistem pernapasan melalui spirakel menuju saluran trakea dan masuk ke dalam jaringan yang menyebabkan gangguan pernapasan dan menjadi toksik sehingga menyebabkan kematian[ $^{[15]}$.

\section{Penentuan lethal concentration-50 (LC50)}

Berdasarkan Tabel 2 telah diketahui nilai ratarata mortalitas kecoa amerika sebesar 33\%, $66 \%$, $86 \%$, dan $96 \%$ dengan konsentrasi $2 \%, 6 \%$, $10 \%$ dan $14 \%$. Selanjutnya, dari data tersebut ditentukan nilai LC $_{50}$. Nilai LC $_{50}$ digunakan untuk mengetahui kemampuan suatu ekstrak dalam membunuh $50 \%$ dari hewan uji yang digunakan. Dalam menentukan nilai LC50 dalam pengujian efektivitas ekstrak biji lamtoro kita perlu menentukan nilai $\log _{10}$ konsentrasi dan nilai probit. Data hasil penentuan nilai LC 50 dapat dilihat pada Tabel 3.

Hasil yang telah diperoleh dibuat grafik yang menunjukkan hubungan antara konsentrasi ekstrak biji lamtoro dengan persentase mortalitas kecoa amerika. Grafik hubungan antara konsentrasi dan persentase kematian kecoa amerika pada 72 jam setelah aplikasi dapat dilihat pada Gambar 2. 
Tabel 3. Hasil analisa data mortalitas kecoa amerika

\begin{tabular}{ccccc}
\hline Konsentrasi (\%) & $\begin{array}{c}\text { Log }_{10} \\
\text { Konsentrasi }\end{array}$ & $\begin{array}{c}\text { Rata-rata } \\
\text { Mortalitas (\%) }\end{array}$ & Nilai Probit & Nilai LC50 (\%) \\
\hline 0 & - & 0 & - & \\
2 & 0.30 & 33 & 4.56 & \\
6 & 0.79 & 66 & 5.41 & \\
10 & 1 & 86 & 6.08 & \\
14 & 1.14 & 96 & 6.75 & \\
\hline
\end{tabular}

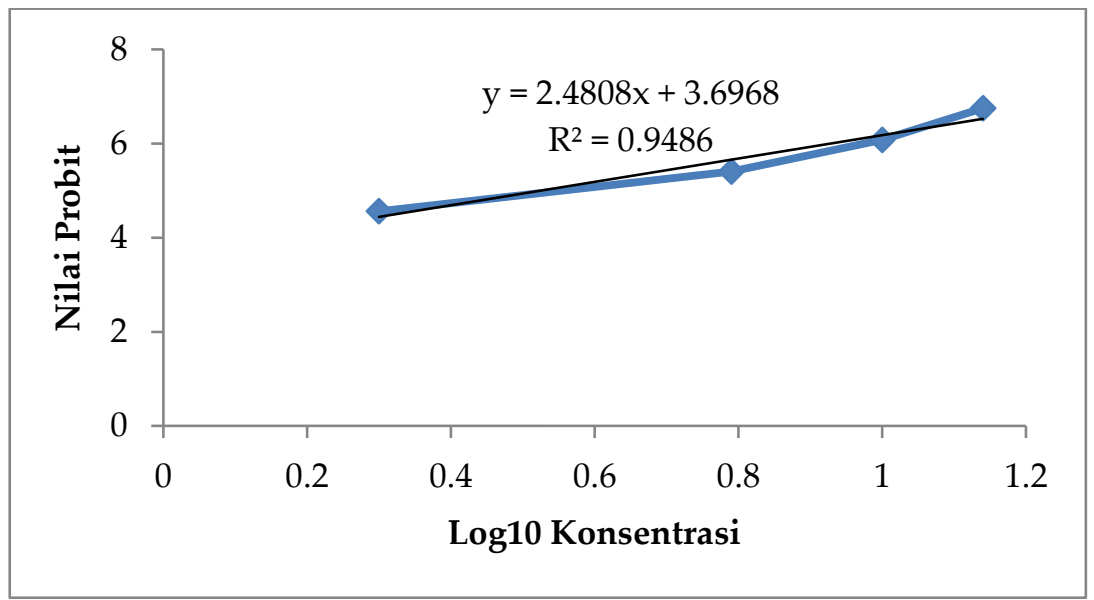

Gambar 2. Grafik hubungan antara konsentrasi dan persentase kematian kecoa amerika pada 72 jam setelah aplikasi.

Dari grafik pada Gambar 2 didapatkan persamaan $\mathrm{y}=2.480 \mathrm{x}+3.696$ dan $\mathrm{R} 2=0.948$. Grafik tersebut digunakan dalam menentukan nilai $\mathrm{LC}_{50}$ dengan mensubstitusikan nilai $50 \%$ sebagai y. sehingga diperoleh nilai LC 50 sebesar $3.35 \%$, artinya mortalitas kecoa amerika mencapai $50 \%$ pada saat konsentrasi ekstrak mencapai $3.35 \%$.

\section{Kesimpulan}

Dapat disimpulkan bahwa ekstrak biji lamtoro (Leucaena leucocephala) efektif terhadap mortalitas kecoa amerika (Periplaneta americana) dengan rata-rata mortalitas sebesar 33\%-96\% pada konsentrasi $2-14 \%$ yang tergolong dalam tingkat efektivitas tipe cukup lemah hingga sangat kuat. Dengan nilai LC 50 sebesar 3.35\%.

\section{Daftar Pustaka}

1. Peraturan Menteri Kesehatan Republik Indonesia, 2017, “Standar Baku Mutu Kesehatan Lingkungan dan Persyaratan Kesehatan Untuk Vektor dan Binatang Pembawa Penyakit Serta Pengendaliannya," Jakarta: Menteri Kesehatan RI.

2. Arimurti, A. R. R., Efektivitas minyak atsiri serai wangi (combypogon nardus) sebagai insektisida alami untuk kecoa amerika (periplaneta americana). $J$. Muhammadiyah Med. Lab. Technol., 1(1): 5560 (2017).

3. Wahyuni, D. \& Anggraini, R., Uji efektifitas ekstrak daun srikaya (Anonna squamosa) terhadap kematian kecoa 
amerika (Periplaneta americana). Phot. J. Sain dan Kesehat., 8(2 SE-Health Sciences): (2018).

4. Krisman, Y., Ardiningsih, P. \& Syahbanu, I., Aktivitas bioinsektisida ekstrak daun belimbing wuluh (Averrhoa bilimbi) terhadap kecoak (Periplaneta americana). J. Kim. Khatulistiwa, 5(3): 1-7 (2016).

5. Agus, I. P. \& Wibawa, H., Uji efektivitas ekstrak mimba (Azadirachta indica A. Juss.) untuk mengendalikan hama penggerek daun pada tanaman Podocarpus neriifolius. J. Agroekoteknologi Trop., 8(1): 20-31 (2019).

6. Kinansi, R., Handayani, S., Prastowo, D. \& Sudarno, A., Efektivitas ekstrak etanol akar tuba (Derris elliptica) terhadap kematian Periplaneta americana dengan metode spraying. BALABA J. Litbang Pengendali. Penyakit Bersumber Binatang Banjarnegara, 14(2): 147-158 (2018).

7. Chahyono, T. B., Maulani, A., Ridwan, M. \& Syarifah, A. N., Antidiabetic drug ethyl acetate fraction of Leucaena leucocephala seed extract in Wistar Aloxan induced. in International Conference: Research and Application on Traditional Complementary and Alternative Medicine in Health Care (TCAM), 22-23 (2012).

8. Suryana, S., Nuraeni, Y. Y. A. \& Rostinawati, T., Aktivitas antibakteri ekstrak etanol dari lima tanaman terhadap bakteri Staphylococcus epidermidis dengan metode mikrodilusi M7-A6CLSI. Indones. J. Pharm. Sci. Technol., 4(1): 1-9
(2017).

9. Endarini, L. H., Farmakognisi dan fitokimia. Kementerian Keseharan Republik Indonesia, 212: (2016).

10. Asmara, A. P., Uji fitokimia senyawa metabolit sekunder dalam ekstrak metanol bunga turi merah (Sesbania grandiflora L. Pers). Al-Kimia, 5(1): 48-59 (2017).

11. Vincent, K., Probit analysis. San Francisco: San Francisco State University, (2008).

12. Susilowati, F., Uji brine shrimp lethality test (Bslt) ekstrak etil asetat Spons calthropella SP. asal zona intertidal Pantai Krakal Gunung Kidul Yogyakarta. Pharm. J. Islam. Pharm., 1(1): 1-5 (2017).

13. Umami, N. T. R. \& Ahsanunnisa, R., Potensi ekstrak daun salam (Syzygium polyanthum) sebagai insektisida hayati terhadap nyamuk Aedes Aegypti. in Prosiding Seminar Nasional Sains dan Teknologi, 2(1): (2019).

14. Wahyuni, D. \& Muktitama, R. E., Uji mortalitas kecoa amerika (Periplaneta americana) menggunakan ekstrak kulit durian (Durio zibethinus Murr). Phot. J. Sain dan Kesehat., 9(2): 9-18 (2019).

15. Al Gifari, S., Efektivitas insektisida ekstrak daun sirsak (Annona muricata L) dalam pengendalian hama ulat grayak (Spodoptera litura) pada tanaman kedelai (Glycine max L) varietas Burangrang. UIN Sunan Gunung Djati Bandung, (2019). 